\title{
HISTOPATHOLOGICAL STUDIES ON PARASITIC AFFECTIONS OF LUNG AND LIVER OF HUMPED CAMELS IN ASWAN SLAUGHTERHOUSES, EGYPT
}

\author{
AHMED K. DYAB ${ }^{1 *}$; MARWA A. AHMED ${ }^{2}$ and AHMED G. ABDELAZEEM ${ }^{3}$ \\ ${ }^{1}$ Department of Parasitology, Faculty of Medicine Assiut University \\ 2 Department of Pathology, Faculty of Veterinary Medicine, Aswan University, Egypt \\ 3 Department of Parasitology, Faculty of Veterinary Medicine, Aswan University, Egypt
}

Received: 30 June 2019; Accepted: 21 July 2019

\begin{abstract}
This study aimed to investigate the different pathological conditions caused by parasitic infection in livers and lungs of slaughtered camels leading to their total or partial condemnation at abattoir. In the present study, 100 lung and 100 liver samples collected from Aswan slaughter-house. Egypt, for histopathological studies. 7 out of $100(7 \%)$ camel lung and only one liver were infected with hydatid cyst the larval stage of Echinoccocus granulosus. Also, 2 out of 100 (2\%) camels liver infected with Fasciola spp. No doubt, hydatidosis and fascioliasis are a public health problem that affects also the human welfare and economy.
\end{abstract}

Key word: Hydatid- Fasciola- liver- lung - camel.

\section{INTRODUCTION}

The camel has been considered an aid to man for thousands of years in many different respects and has a high economic value by providing meat, milk and wool as well as transportation and labor. Due to its physiological attributes, the camel is the most suitable domestic mammal for use in climatic extremes. Understanding and utilizing this special gift could lead to the development of camel farms in famine areas and a reduction in human starvation. Pathogenic diseases, poor nutrition and traditional management systems have restricted their full utilization (Bekele, 2002).

Parasitic infection is of economic and public health importance, the most obvious economic losses usually caused by the condemnation of the viscera and sometimes all carcasses and reduce the meat, wool and milk production. Several parasites have been emerged as significant causes of food borne illness, which range from mild discomfort to debilitation and possibly death. One of the most important parasitic diseases, which is indirectly transmissible to human being, is the hydatid diseases or echinococcosis (Hassanin et al., 2013).

Liver diseases are relatively common but often occur in the absence of specific clinical signs. The liver

Corresponding author: Dr. Ahmed G. Abdelazeem E-mail address: doctorahmedvetpara@yahoo.com Present address: Department of Parasitology, Faculty of Veterinary Medicine, Aswan University, Egypt has considerable power of regeneration, severe loss of hepatic cells can be restored and normal architecture is retained. However, if the loss of the hepatic cells is more severe, cirrhosis can result. Cirrhosis is an irreversible disturbance which may affects the entire liver and may regenerate in a nodular pattern. The regenerating nodules lack the organized lobular structure of the normal liver and the blood haphazardly reach to it resulting in an inefficient organ that is prone to liver failure. Liver failures do not appear until 70-80\% of the functional capacity is lost. Hydatid liver disease and migration of the immature flukes especially Fasciola hepatica, produces hemorrhagic tracks of necrotic liver parenchyma. Mature flukes reside in the larger bile ducts and cause cholangitis or cholangiohepatitis which may lead to stenosis of the duct (El-mahdy et al., 2013).

Hence, the present study was designed to provide preliminary information on the prevalence rates, along with histopathological examination caused by hydatid cyst and Fascioliasis in camels slaughtered in Aswan slaughterhouses.

\section{MATERIALS AND METHODS}

Study area and animals: During the period extended from November 2018 to April 2019, in different slaughterhouses of Aswan Governorate (Egypt). A total of 100 camels were thoroughly examined during the post-mortem examination for detection of hydatid cyst and Fasciola spp. in slaughtered carcasses. 
Detection of hydatid cysts: The lung and liver was examined visually followed by palpation with the fingers, which usually pressed, firmly into the substance of the examined organs to locate the smallest and deepest cysts. Multiple incisions were done to detect deep hydatid cyst.

Detection of Fasciola spp.: Palpation and many incisions were made through each liver and bile ducts. Then careful visual examination and identification of immature or mature liver flukes.

\section{Histopathological examination:}

The lungs and livers were appropriately examined for the presence of hydatid cysts, Fasciola spp. and their gross pathology, the lesions were characterized following the procedures. The parts of the affected organs were sampled and immersed in $10 \%$ neutral buffered formalin. The fixed tissue samples of about $1 \mathrm{~cm}^{3}$ in size were trimmed to $5 \mathrm{~mm}$ and processed (dehydrated through a series of ascending grades of alcohol, cleared in three changes of xylene and impregnated with paraffin wax) and finally, embedded in melted paraffin $\left(60^{\circ} \mathrm{c}\right)$. The tissues were then sectioned at $5 \mu \mathrm{m}$ and stained routinely with hematoxylin and eosin, for microscopic examination (Belina et al., 2015).

\section{RESULTS}

\section{1- Prevalence}

7 out of $100(7 \%)$ camel lungs and only one liver were infected with hydatid cyst the larval stage of Echinoccocus granulosus. While Fasciola spp. detected only on two livers with percentage $2 \%$ of examined camels.

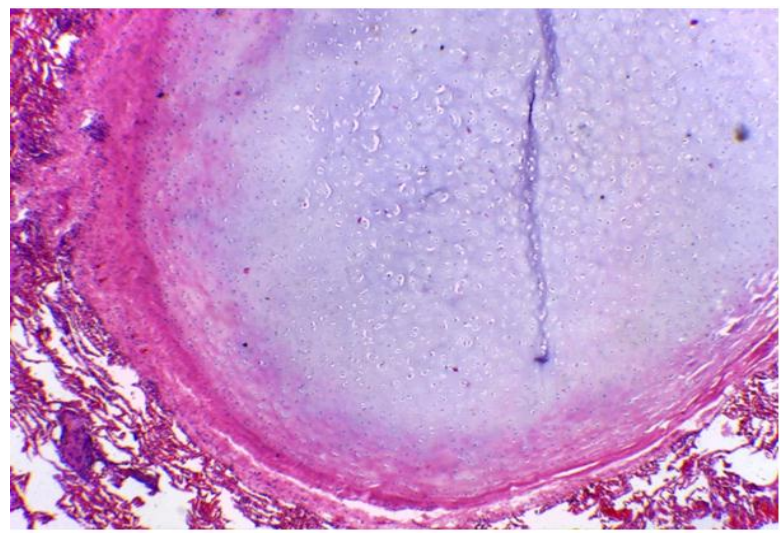

Fig. 1: The hydatid cyst wall formed of thick fibrous connective tissue, lumen filled with fluid and the neighboring tissues of lung showed atelectasis, emphysema and hemorrhage within the camels lung (H\&E .X10).

\section{2- Histopathology}

a- Hydatid cysts in lung: Grossly the obtained hydatid cysts were spherical shape, uniloccular, 57\% (4 in number) single and $43 \%$ (3 in number) multiple, greyish-white color, of variable sizes cysts were mostly appeared elevated from lung tissue. These cysts formed from thick fibrous capsule of host, double layers (elastic cellular laminated layer externally, germinal layer internally) and lumen. This lumen contained fluid. Microscopically the cysts, showed the typical structure of common hydatid cyst, consisted of germinal layer, cuticular membrane, fibrous tissue capsule and cellular infiltration. The fibrous capsule consisted of thick connective tissue layer which has infiltrated with aggregates of lymphocytes and plasma cells (Fig. 1, $2,3)$

b- Hydatid cyst in liver: Grossly the hydatid cyst in the liver not recognized protruding on the surface but was found deeply in liver tissue and very small size. Microscopically the determined cysts filled with caseated material intermixed with dystrophic calcification and surrounded by fibrous capsule and mononuclear inflammatory cells (Fig. 4).

c- Chronic Fascioliasis: Grossly the liver was greatly firm, pale with thickened hepatic capsule, the wall of bile ducts was thickened and whitish in color but no any flukes were detected. Microscopically liver flukes were observed within a migratory tract with evidences of necrosis, hemorrhage, inflammatory cell reaction and connective tissue proliferation (Fig. 5). The portal area showed evidences of portal cirrhosis with hyperplasia of bile duct (Fig. 6)

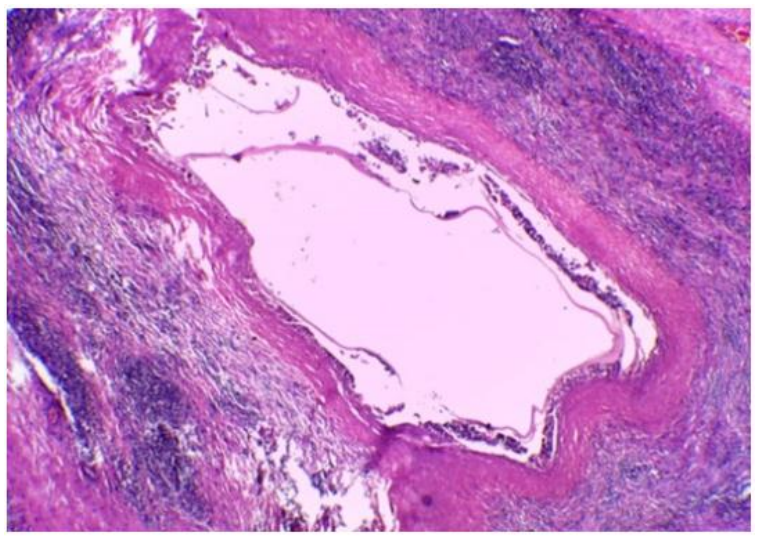

Fig. 2: The hydatid cyst wall formed of thick fibrous connective tissue with inflammatory cellular reaction (mainly lymphocytes) within the camels lung (H\&E.X4). 


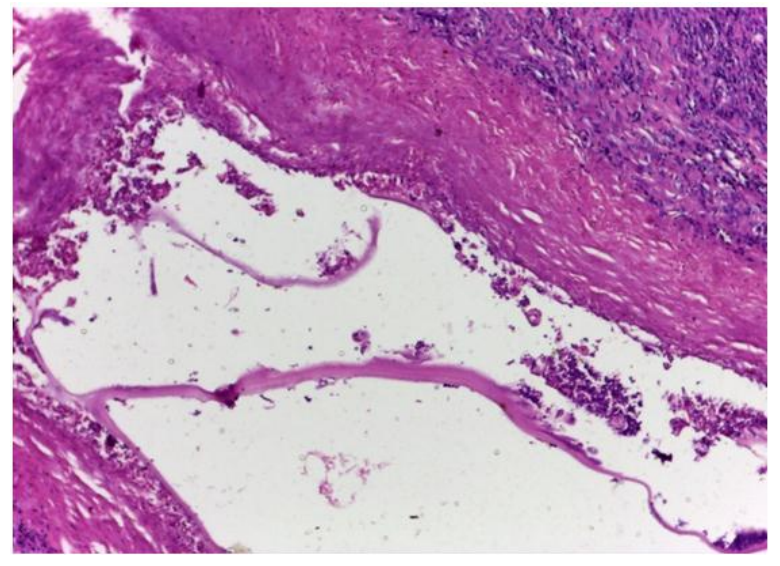

Fig. 3: The hydatid cyst wall with eosinophilic laminated material, inflammatory cells within the camels lung (H\&E.X10).

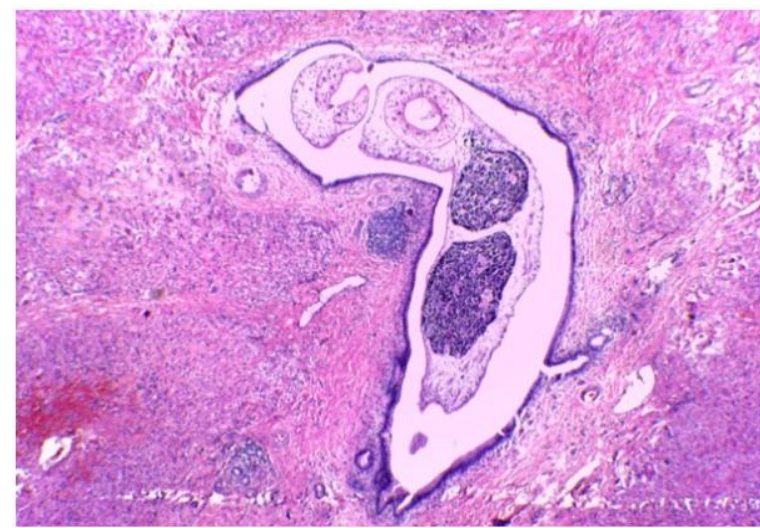

Fig. 5: Liver of camel showing adult fasciola worm and migratory tracts. Note presence of necrosis, hemorrhage, lymphocytic and eosinophilic cell infiltration and fibrous tissue formation (H\&E. $\mathrm{X} 10)$.

\section{DISCUSSION}

- Concerning to Hydatid cyst, it was $7 \%$ in camels lung and $1 \%$ in camels liver, that agree with that mentioned by Kasem (2013) in Aswan (Egypt), who reported the similar percentage $(6.57 \%$ and $0.37 \%)$ in camels lung and liver respectively. While the higher percentage was mentioned by Salih et al. (2011) in Ethiopia, who determined $67.3 \%$ in lung alone, $25 \%$ both liver and lungs, $6.73 \%$ in liver only. Bahnass (2009) in Zagazig (Egypt), who detected in liver and lung with percentage of $9.02 \%$ and $90.9 \%$ respectively. Dyab et al. (2018) in Aswan (Egypt), studied the cystic hydatidosis in $8.32 \%$ mostly found in camel lung. Hence it is clear that the most of the previous authors reported the lungs as the preferred location of hydatid cyst in camels.

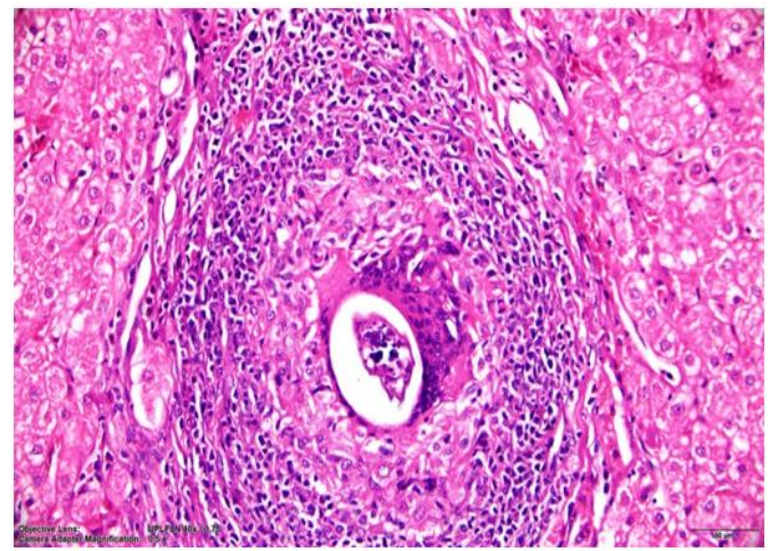

Fig. 4: The hydatid cyst filled with caseated material intermixed with dystrophic calcification and surrounded by fibrous capsule and mononuclear inflammatory cells within the camels liver (H\&E.X10).

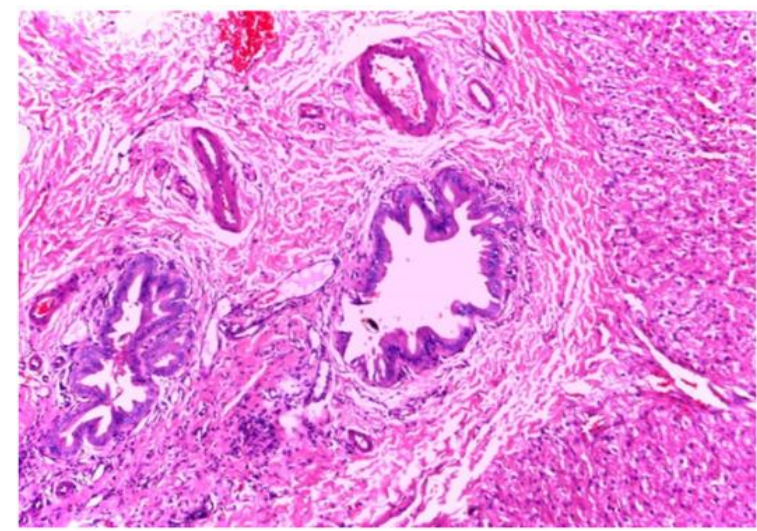

Fig. 6: Liver from camel showing Hyperplasia, thickening of bile duct and fibrous proliferation in portal area causing pressure atrophy of liver cells (H\&E.X10).

- Concerning to fascioliasis: 2 out of $100(2 \%)$ camels livers infected with Fasciola spp., that agree with detected by Al-Rawashdeh et al. (2000) in Jordan, who studied Fasciola hepatica in 2\% of examined camels, and higher than that mentioned by Borai et al. (2013) in Kalubia (Egypt), who found Fasciola spp. in $(0.15 \%)$ of examined camel. It is worth mentioning that, the present result was obtained for the first time infection with Fasciola spp. in Aswan Governorate and detected only by histopathological examination using ordinary microscope. The lowest prevalence of fascioliasis recorded in camels could be attributed to the nature of their life in the desert away from the intermediate host of the trematode and feeding on dry pasture as well as the liver of camels has more fibrous tissue between the lobules and in the hepatic capsule than 
in other herbivores though penetration of the liver fluke is more difficult according to (Salim, 2000).

Regarding the pathology of hydatid cyst: According to our study, the pathological changes observed in lung infected with hydatidosis showed the typical structure of common hydatid cyst, consisted of germinal layer, cuticular membrane, fibrous tissue capsule and cellular infiltration. The fibrous capsule consisted of thick connective tissue layer which has infiltrated with aggregates of lymphocytes and plasma cells; this result was previously obtained by (Ahmed, 2016). The fibrous capsule produced by inflammatory reaction between host and parasite and called perikyste, as mentioned by Khadidja et al. (2014) and Bacciarini et al. (2004). While the determined liver cyst filled with caseated material intermixed with dystrophic calcification and surrounded by fibrous capsule and mononuclear inflammatory cells, that agree with mentioned by (Borai et al., 2013).

Regarding to the pathology of Fasciola spp.: Grossly the liver infected with Fasciola was greatly firm, pale with thickened hepatic capsule, the wall of bile ducts was thickened and whitish in color but no any flukes were detected. Microscopically liver flukes were observed within migratory tract, in addition to dystrophic calcification, this result previously determined by (Eid et al., 1998). The migratory tracts showed necrosis, hemorrhage, lymphocyte, eosinophilic infiltration and fibrous tissue formation occur due to infection with Fasciola spp. similar picture was reported by (Borai et al., 2013).

\section{CONCLUSION}

Slaughterhouses are safe guards for human health and can be pools for zoonosis dissemination with the lack of condemned organs follow up and incineration. So public health extension awareness about the risks of eating raw livers, lungs and meat, also the future periodic surveillance of camels allover Egyptian Governorates for hydatid cyst and Fasciola spp. infection is strongly needed for designing future prevention and control measures in camels.

\section{REFERENCES}

Ahmed, MA. (2016): Some studies on metacestodes in slaughtered animals in Aswan Governorate. MSc.D. Department of parasitology, Faculty of Veterinary Medicine, Assiut University.

Al-Rawashdeh, OF.; Al-Ani, FK.; Sharrif, LA. and Al-Qudah, KM. (2000): A survey of camel (camelus dromedarius) diseases in jordan. Journal of Zoo and Wildlife Medicine 31(3): 335-338.

Bacciarini, LN.; Gottstein, B. and Pagon, O. (2004): Hepatic alveolar echinococcosis in cynomolgus monkeys (Macaca fasciolaris). Vet. Pathol. 41: 229- 234.

Bahnass, MMM. (2009): Studies on hydatidosis in some farm animals. Ph.D. Department of animal's medicine, Faculty of veterinary medicine, Zagazig University.

Bekele, T. (2002): Epidemiological studies on gastrointestinal helminths of dromedary (Camelus dromedarius) in semi-arid lands of eastern Ethiopia. Vet. Parasitol., 105: 139-152.

Belina, D.; Demissie, T.; Ashenafi, H. and Tadesse, A. (2015): Comparative pathological study of liver fluke infection in ruminants. Indian $\mathbf{J}$. Vet. Pathol., 39(2): 113-120.

Borai, MGE.; Nagi, AA. and Gab-Allah, MS. (2013): Comparative pathological studies on parasitic affections of liver in farm animals. Benha Veterinary Medical Journal, Vol. 25, No. 2: 284-295.

Dyab, AK.; Marghany, ME. and Othman, RA. (2018): Hydatidosis of camel and sheep slaughtered in Aswan governorate southern Egypt. Russian Journal of parasitology, 12(3): 33-41.

Eid, RA.; El-Mahdy, MM.; Hamouda, MA. and Darwish, FMM. (1998): Some studies on parasitic liver infestations of camels in Egypt. Assiut Vet. Med. J. Vol., 38(76): 121-137.

El-mahdy, MM.; Bakeer, AM. and Al Wazzan, AA. (2013): Pathological Studies on Liver affections in Saudi Arabia Camels. Egypt. J. Comp. Path \& Clinic Path. Vol.26 No. 1; 85108.

Hassanin, FS.; Shaltout, FAE. and Afifi, MEM. (2013): parasitic affections in edible offal. Benha Veterinary Medical Journal, Vol. 25, No. 1: 46-55.

Kasem, FSS. (2013): Hydatid cyst in dromedary camel at Aswan Governorate. Ph.D. Department of Animal medicine. Assiut University.

Khadidja, H.; Achour, Y. and Houcin, B. (2014): Histological appearance of Echinococcus granulosus in the camel species in Algeria. Bulletin UASVM Vet. Med. 71 (1); 79-84.

Salih, M.; Degefu, H. and Yohannes, M. (2011): Infection rates, cyst fertility and larval viability of hydatid disease in camels (Camelus dromedarius) from Borena, Kereyu and Harar areas of Ethiopia. Global Veterinaria 7 (6): 518-522.

Salim, MK. (2000): Cited in "camel: a new Egyptian host for Fasciola gigantica" J. Egypt. Soc. Parasitol., 30(2): 451-454. 


\section{دراسات هستوباثولوجية على العدوى الطفيلية للرئة والكبد فى الجمال المذبوحة بمجازر أسوان- مصر \\ أحد كمال دياب ، مروقة أحد أحد ، أحد جارح عبل العظيم}

E-mail: doctorahmedvetpara@yahoo.com Assiut University web-site: www.aun.edu.eg

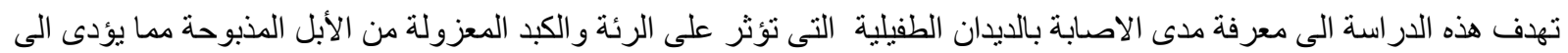

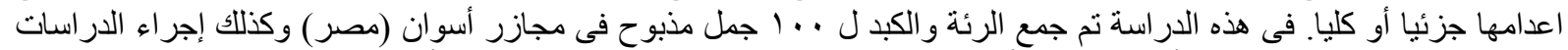

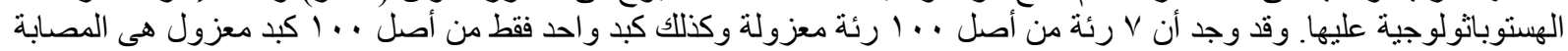

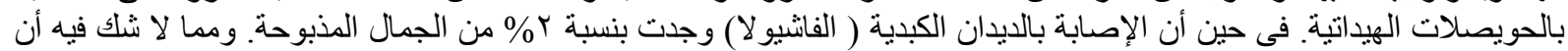

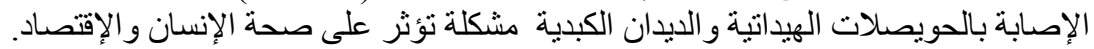

